\title{
THE EVALUATION OF THE RELATIONSHIPS AMONG PERCEIVED RISK OF DELIVERY, ONLINE PURCHASE ATTITUDE, AND INTENTION OF CONSUMERS ${ }^{1}$
}

Hayriye Nur BAŞYAZICIOĞLU22

\author{
Received Date (Başvuru Tarihi): \\ Accepted Date (Kabul Tarihi): \\ Published Date (Yayın Tarihi):
}

$17 / 02 / 2020$

$24 / 09 / 2020$

$10 / 12 / 2020$
ABSTRACT

Keywords:

Perceived Risk,

Online Purchase Intention,

Online Purchase Attitude

JEL Codes:

M3, M31, M39
Although online shopping offers many benefits to consumers such as product variety, price comparison opportunity, space, and time convenience, it is seen that the online purchase intention of consumers is affected by the risks of online shopping. In the literature, the risks of online shopping have been examined in general, but it has been found that delivery risk, one of the essential elements of online shopping, has not been addressed in detail. Therefore, this study aims to examine the perceived delivery risks of consumers in online shopping. For this purpose, primary data was collected with a face-to-face survey method from 482 respondents. The confirmatory factor analysis determined that the perceived delivery risk consisted of four factors, namely product risk, non-delivery risk, financial risk, and time risk. In the second stage, the effects of these risks on online purchase attitude and intention were analysed with path analysis. Therefore, this study is thought to fill an essential gap in the literature and will guide future studies.

\section{TÜKETICILLERIN TESLIMAT RISSKI ALGILARI, ONLINE SATIN ALMA TUTUMLARI VE ONLINNE SATIN ALMA NIYETLERI ARASINDAKİ İLIŞKILERINN DEĞERLENDİRILMESİ}

$\ddot{O Z Z}$

\section{Anahtar Kelimeler: \\ Algilanan Risk, \\ Online Satın Alma Niyeti, \\ Online Satın Alma Tutumu}

\section{JEL Kodlar:}

M3, M31, M39
Online alışveriş tüketicilere ürün çeşitliliği, fiyat karşılaştırma imkanı, mekan ve zaman kolaylığı gibi birçok fayda sunsa da, tüketicilerin online satın alma niyetlerinin online alı̧̧verişin taşıdığı risklerden etkilendiği görülmektedir. Literatür incelemesi yapıldığında, online alışveriş risklerinin genel çerçevede incelenmiş olduğu, ancak online alışverişin gerek tüketiciler gerekse de işletmeler için en önemli unsurlarnndan biri olan teslimat riskinin detaylı olarak ele alınmadı̆̆ı tespit edilmiştir. Bu nedenle, bu çalışma, tüketicilerin çevrimiçi alışverişte algıladıklar teslimat risklerini kapsamlı bir şekilde incelemeyi amaçlamaktadır. Bu amaçla, 482 katılımcıdan yüz yüze anket yöntemi ile birincil veriler toplanmıştır. Doğrulayıc faktör analizi ile algılanan teslimat riskinin ürün riski, teslim edilmeme riski, finansal risk ve zaman riski olmak üzere dört faktörden oluştuğu belirlenmiştir. İkinci aşamada ise, bu risklerin online satın alma tutum ve niyetine etkileri yol analizi ile analiz edilmiştir. Bu sayede, bu çalışmanın literatürdeki önemli bir boşluğu dolduracă̆ı ve gelecekteki çalışmalara yön vereceği düşünülmektedir.

\footnotetext{
${ }^{1}$ This article is an extended and improved version of the paper published in the proceedings of The 19th International Business Congress hosted by Erciyes University.

${ }^{2}$ Erciyes University, Faculty of Economics and Administrative Sciences, Department of Business, nur@erciyes.edu.tr,
} https://orcid.org/0000-0001-5076-6870 


\section{INTRODUCTION}

According to the report of the development of e-commerce which was published by Deloitte company in 2019, many factors such as global economic trends, demographic factors, developments in internet infrastructure, the widespread use of mobile devices, increase in logistics and payment service providers have ensured the rapid spread of e-commerce all over the world. Globally, it is seen that 4.4 billion people had internet access (HOOTIE and We Are Social, 2019) and these people composed an e-commerce volume of \$2.9 trillion (Lipsman, 2019). Turkey also showed that it had followed the global trends with its e-commerce volume of $\$ 14.6$ billion in 2019 (TUBISAD, 2019:13). These statistics reveal the importance of online shopping.

The rapid increase in online shopping volume all over the world is sourced by the various benefits offered by online shopping to consumers. These benefits can be basically divided into two categories as functional benefits and non-functional benefits (Forsythe et al., 2006:56). Functional benefits are related with convenience (Bhatnagar \& Ghose, 2004: 1353), wider product assortment (Chang, 2011:159), competitive prices (Suhaily \& Soelasih, 2017:113), and ease of use (Choi \& Lee, 2003:50). On the other hand, non-functional benefits include hedonistic motivations such as enjoy from shopping experience (Başyazıcıŏglu \& Leblebici Koçer, 2018:118), and social needs (Ozen \& Engizek, 2014:82).

Although the benefits of online shopping appeal consumers, online shopping includes significant uncertainties in its nature. Online shopping is realised in a digital market environment so that an impersonal communication with spatial and temporal differences between consumer and organisation is occurred (Naiyi, 2004:177). Consumers decide to place an order by evaluating the product information written on the website, and they cannot experience the product before they get it. Consumers need to make payment before the product is delivered by sharing their personal and credit card information with the website to place their order. Besides, there are uncertainties about after-sales service provided by organisations in online shopping (Pappas, 2016:93). Besides, consumers worry about trade fraud and security issues in their online shopping experience. These features of online shopping pose essential risks for consumers. Although there is always a risk in traditional trade, consumers 
think that online shopping involves much more risk than traditional trade (Ariff et al., 2014:2) and risk perception of consumers is regarded as an important barrier for online shopping behaviour (Featherman \& Pavlou, 2003:452). Although online shopping offers various benefits to consumers, consumers are more motivated to minimise risks than maximise the benefits (Mitchell, 1999:163). Thus, consumers' perceived risk of online shopping shapes their online shopping behaviours (Zhang et al., 2011:2). This indicates the importance of examination of consumer risk perception in online shopping.

Perceived risks of online shopping have been studied in the literature with different components such as financial risk, performance risk, psychological risk, physical risk, security risk and time risk (Featherman \& Pavlou, 2003; Zheng et al.2012). When the studies in the literature are examined, it is understood that these studies examined the perceived risk of online shopping in the general framework so that they did not investigate the perceived risks in detail.

When main concerns of the consumer in online shopping were asked, consumers explained their fear about the facts that the product is damaged during transportation, delivery takes a long time, the product is delivered to a wrong person, and the product is lost in transportation (Naiyi, 2004:180). Therefore, it is also considered that it is imperative for consumers to deliver the products they order to them at the appropriate time without any problems. Thus, in addition to the risks examined in the literature, the delivery problem is considered as one of the most critical risks in online shopping. However, it was determined that this situation was not emphasised in the literature. Therefore, the purpose of this study is to examine the relationships among consumers' delivery risk perception, online purchase attitude and intention. In line with this purpose, the elements that constitute the delivery risk perception will be determined by confirmatory factor analysis. The relationships among determining factors, online purchase attitude and intention will be analysed using path analysis. In this way, it is thought that the study will make an important contribution to the literature. 


\section{LITERATURE REVIEW}

Risk can be defined as the estimated loss in the likelihood that an action will result in undesirably (Hassan et al., 2006:139). Although there are always significant risks in traditional trade, consumers perceive online shopping as riskier (Thakur \& Srivastava,2015:151) due to the imperfect system of online shopping such as credit system, payment system, security system and delivery system, and digital network problem such as unclear product information, risk of fake good and postponement of accomplishment sense (Hong \& Yi, 2012:1305-1306).

When the studies in the literature are examined, the risks that affect the online purchasing decision of consumers are collected under six headings: Financial risk, product risk, time risk, security risk, social risk, psychological risk. Financial risk refers to the need for additional payments after purchasing the product online (Crespo, Del Bosque \& Salmonos Sanchez, 2009:263). Product risk is expressed as the unfavourable result that the ordered product does not perform as expected (Javedi et al., 2012:83). Time risk explains the length of time spent doing research on the internet to purchase products (Ariff et al., 2014:3). Security risk refers to the danger of copying credit card information of consumers in online shopping (Thakur \& Srivastava,2015:153) and the danger of using their personal information for different purposes (Nyshadham, 2000:145). Social risk explains the loss of social status of consumers as a result of the product purchased online (Ko et al., 2004:21). Psychological risk is expressed as the risk of losing self-confidence and being disappointed, especially if the product consumer wants to buy expensive but the consumer cannot buy the product in the online purchasing process (Featherman \& Pavlou, 2003:455).

In addition to these risks, a limited number of studies in the literature have drawn attention to the importance of the risk of delivery. Delivery risk includes consumer concern which is related to loss of purchased product during the delivery process, product damage during transportation and delivery of the product to the wrong place (Ariff et al., 2014:4). In addition to these fears, the failure to deliver the product on time is one of the important factors in online shopping for consumers (Naiyi, 2004:180). In the literature, the limited number of studies which examined the delivery risk of online shopping is found. 
Choi and Lee (2003) examined the effects of online risk factors on purchase intention. They studied with three risk factors, namely product delivery, transaction security and customer service. They found that these risk factors harmed purchase intention of both Korean and American consumers.

Naiyi (2003) identified seven perceived risks in online shopping. These were fraud risk, delivery risk, financial risk, process and time loss risk, product risk, privacy risk and information risk.

Zhang, Tan, Xu, and Tan (2011) investigated the influence of consumer perceived risk on online shopping behaviour. They studied with eight perceived risk such as health risk, quality risk, privacy risk, economic risk, time risk, social risk, delivery risk, and after-sale risk. Their findings showed that health risk, quality risk, time risk, delivery risk, and after-sale risk affect the online shopping behaviour of consumers. However, the effects of privacy risk, social risk, and economic risk on online shopping behaviour were statistically insignificant.

Claudia (2012) interviewed with 30 internet users. The semi-structured interview was used to assess the risk perception of consumers in terms of online purchasing. At the end of this study, it was understood that Romanian consumers had a high degree of risk in online shopping. Their risk perception was sourced by financial risk, privacy risk, performance risk, delivery risk, time risk, psychological risk, and social risk. The result of this study explained low e-commerce adoption in Romania.

Javadi, Dolatabadi, Nourbaksh, Poursaeedi, and Asadollahi (2012) investigated online shopping behaviour of Iranian consumer with the effects of perceived risk, return policy, service-infrastructure variables, domain-specific innovativeness, subjective norms, and perceived behavioural control. They divided perceived risk into four factors such as financial risk, product risk, convenience risk, and non-delivery risk. In the conceptual model, it is tested the effects of perceived risk, return policy and service-infrastructure variables on attitude. Then in the second stage, the impacts of domain-specific innovativeness, attitude, subjective norms, and perceived behavioural control on online shopping behaviour. It is found that financial risk and delivery risk harmed online shopping attitude and attitude also affected online shopping behaviour. 
Ariff, Sylvester, Zakuan, Ismail, and Ali (2014) analysed the online shopping behaviour of Malaysian consumers. The perceived risk of consumers was divided into four categories such as product risk, financial risk, convenience risk and non-delivery risk. Thus, the relationships among perceived risk, attitude, and online shopping behaviour were tested in this framework. The findings of study indicated that financial risk, non-delivery risk and product risk affected attitude negatively, but convenience risk had a positive effect on attitude. The effect of attitude on online shopping behaviour was positive.

Hong, Zulkiffli, and Hamsani (2016) examined the effect of perceived risk on online purchase attitude. They divided perceived risk into four factors such as product risk, financial risk, non-delivery risk, and psychological risk. Research findings showed that the effects of product risk, financial risk and non-delivery risk on attitude is complimentary; however, the effect of psychological risk on attitude was negative.

Tham, Dastane, Johari, and Ismail (2019) evaluated the effects of perceived risk on the online behaviour of Malaysian consumers. They used five types of perceived risk such as financial risk, convenience risk, non-delivery risk, return policy risk and product risk. This study indicated that the effects of product risk, convenience risk and return policy risk on online behaviour were positive. Non-delivery risk hurt the online behaviour of consumers.

Although these studies did not examine delivery risk in detail, they indicated that delivery risk harmed online purchase attitude, intention, and behaviour. However, the definition of delivery risk includes various items of transportation such as financial cost of delivery, the possibility of product loss and damaged, non-delivery of product and delayed delivery of the product. The studies in the literature did not explain which features of the delivery risk cause negative impacts on online purchase attitude, intention, and behaviour of consumers. For this reason, this study aims to investigate delivery risk in detail and to probe the effects of delivery risk on online purchase attitude and intention of the consumer. 


\section{CONCEPTUAL FRAMEWORK AND HYPOTHESIS DEVELOPMENT}

\subsection{Perceived Delivery Risks}

Perceived risk in online shopping is defined as the consumers' assessment of the possibility of the occurrence of dissatisfied consequence after online purchase decision (Hong, Zulkiffli \&Hamsani, 2016:14). Risk perception of consumers arises due to the uncertainty and possible adverse outcomes (Dowling \& Staelin,1994:119). Spatial and temporal difference between consumers and organisations in the digital market environment magnify uncertainties so that consumers think that online shopping involves much more risk than traditional shopping (Forstyhe et al.,2006:57). Perceived risk is vital for organisations because it affects consumer attitude and intention negatively (Ariff et al.,2014:4).

Perceived delivery risk is used to define potential failure of delivery in online shopping. Delivery risk is one of the most critical risk in online shopping for both organisations and consumers. The negative effect of delivery risk on consumer satisfaction leads businesses to be more attentive and careful about the distribution process (Cao, Ajjan \&Hong, 2018:409). In this way, businesses strive to minimise consumers' perceived delivery risk. On the other hand, $68 \%$ of consumers stated that they worried about the delivery problem in online shopping (Claudia, 2012:64). These problems in delivery process occur for different reasons such as wrong delivery, nondelivery, damaged delivery, and delayed delivery (Ariff et al.,2014:4). Besides, consumers are concerned about whether the product meets the expectation or not (Choi \& Lee, 2003:52). Finally, an extra charge of delivery is evaluated as the financial cost of delivery (Naiyi, 2003:179). By regarding different reasons of the delivery problem in online shopping, the perceived delivery risk is investigated with its different components such as the financial risk of delivery, product risk of delivery, non-delivery risk, and time risk of delivery.

The financial risk of delivery is different from the financial risk of online shopping. The financial risk of online shopping includes purchase price, maintenance cost, and financial loss due to fraud (Featherman \&Pavlou, 2003:455). However, the financial risk of delivery refers to the consumer concern of extra charge of delivery in 
online shopping. Since perceived risk hurts online purchase attitude of consumers, the $\mathrm{H}_{1}$ hypothesis is posited.

$H_{1}$ : There is a negative relationship between financial risk of delivery and online purchase attitude.

Product risk of delivery is different from the product risk of online shopping. Product risk of online shopping covers the consumers' concern related to the quality and performance of the product, and product-related problem (Naiyi, 2003:180). On the other hand, product risk of delivery includes the concerns that the product is damaged during the transportation, the wrong or defective product is sent, and the incoming product does not meet the expectations. Because of the negative effect of perceived risk on online purchase attitude, $\mathrm{H}_{2}$ hypothesis is proposed.

$\mathrm{H}_{2}$ : There is a negative relationship between product risk of delivery and online purchase attitude.

Non-delivery risk includes the concern about the delivery of the product to the correct address and the correct person (Hong, Zulkiffli \&Hamsani, 2016:15). Besides, it includes what will be happened if the receiver is not found on the address. In literature, there is a negative relationship between perceived risk and online purchase attitude. Thus, $\mathrm{H}_{3}$ hypothesis is proposed.

$\mathrm{H}_{3}$ : There is a negative relationship between non-delivery risk and online purchase attitude.

Finally, time risk of delivery is different from the time risk of online shopping. Time risk of online shopping includes time spent for searching, purchasing, and replacing the unsatisfied products (Zhang et al., 2012:3). Unlike the time risk of online shopping, time risk of delivery refers to the concern long delivery time and delayed delivery. Since a negative relationship between perceived risk and attitude is found, $\mathrm{H}_{4}$ hypothesis is posited.

$\mathrm{H}_{4}$ : There is a negative relationship between time risk of delivery and online purchase attitude.

\subsection{Online Purchase Attitude and Online Purchase Intention}

Online purchase intention is originated from behavioural intention in the Theory of Planned Behaviour. Behavioural intention is used to explain the intention of a consumer to conduct a specific behaviour (Ajzen \&Fishbein, 1977:888). Based on the 
Theory of Planned Behaviour, there is a strong positive relationship between intention and behaviour so that behavioural intention can be used to predict the actual behaviour of consumers (Thakur \&Srivastava, 2014:151).

Attitude is defined as the consumers' overall feelings and emotions to a particular object and action (Ajzen \&Fishbein, 1977:888). Therefore, consumers' feelings and emotions to online shopping behaviour shape consumers' online purchase attitude. While consumers develop positive attitude thanks to positive feelings, negative feelings also cause a negative attitude. (Ariff et al.,2014:4). Based on the Theory of Planned Behavior attitude also affect the intention. Therefore, the $\mathrm{H}_{5}$ hypothesis was proposed.

$\boldsymbol{H}_{5}$ : There is a positive relationship between online purchase attitude and online purchase intention.

\subsection{Conceptual Model}

The conceptual model of this study examines the relationship between perceived risk factors and online purchase attitude and the effect of online purchase attitude on online purchase intention. The conceptual model is shown in Figure 1.

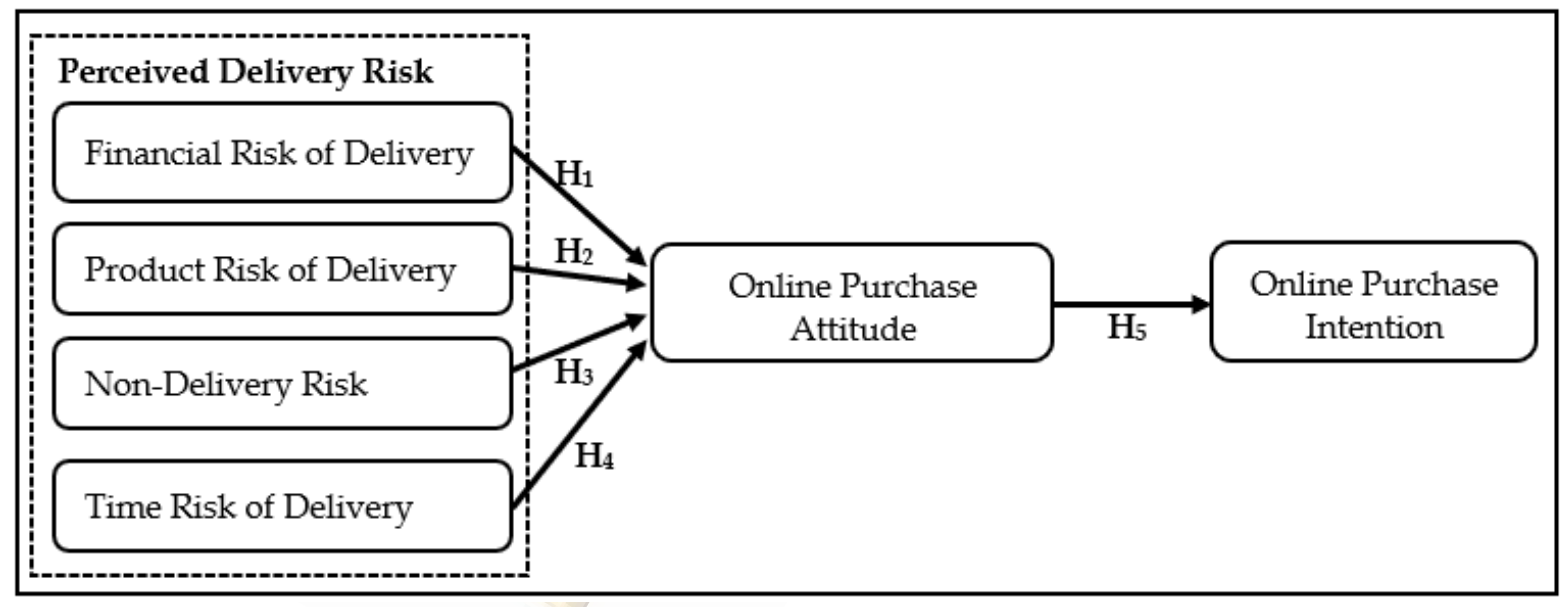

Figure 1. Conceptual Model

\section{METHODOLOGY}

It is observed that online spending of consumers has continued to increase for years. Although the advantages of online shopping appeal to consumers, consumers have been still sceptical about online shopping due to its specific risks. It is noticed that one of the most worrying situations after giving an online order is to receive the 
product without any problem for consumers (Arriff et al. 2014:4). On the other hand, product delivery is also important for organisations in terms of its significant impact on consumer satisfaction (Keeney, 1999:539). By regarding these facts related to online shopping, it is understood that delivery risk is an important issue for both consumers and organisations in online shopping. The risks of online shopping for consumers have been investigated in the literature in general; however, no studies that comprehensively address delivery risk have been found. Thus, this study aims to examine the relationships among the perceived delivery risk, online purchase attitude and intention of consumers so that, this study will make a significant contribution to the literature and help further studies in the future. By this purpose, a survey form was created based on the previous scales of studies in the literature (Feather \& Pavlou, 2003; Lopez-Nicholas \& Molina-Castello, 2008; Naiyi, 2004; Nepomuceno, Laroche, \& Richard, 2013; Pappas, 2015). The survey form consisted of 27 five-point Likert-type items and demographic questions such as age, gender, marital status, and monthly income level. Convenience sampling was used in research due to time and budget constraints. Data was collected from 482 students at Erciyes University in Turkey as a result of the 3-week face-to-face survey in the summer of 2018.

\section{DATA ANALYSIS AND FINDINGS}

Data collected from respondents were analysed by statistical methods such as descriptive statistical methods, reliability and validity analysis, confirmatory factor analysis and path analysis.

\subsection{Demographic Characteristics of Sample}

The respondent profile is analysed by the descriptive statistical method, and the findings are listed below in Table 1. 
Table 1. Demographic Characteristics

\begin{tabular}{|l|l|c|c|}
\hline \multicolumn{2}{|c|}{ Demographic Characteristics } & Frequency & Percentage \\
\hline Gender & Female & 261 & 54.1 \\
& Male & 221 & 45.9 \\
\hline \multirow{2}{*}{ Age } & $18-20$ & 104 & 21.6 \\
& $21-23$ & 266 & 55.2 \\
& 24 and above & 112 & 23.2 \\
\hline \multirow{2}{*}{ arital Status } & Single & 430 & 89.2 \\
& Married & 52 & 10.8 \\
\hline \multirow{2}{*}{ Income } & 999 TL and below & 328 & 68.0 \\
& 1000-1999 TL & 108 & 22.4 \\
& 2000 TL and above & 46 & 9.6 \\
\hline TOTAL & $\mathbf{4 8 2}$ & $\mathbf{1 0 0}$ \\
\hline
\end{tabular}

Table 1 shows the demographic characteristics of the sample. When Table 1 is examined, it is seen that $54.1 \%$ of the participants are women and $45.9 \%$ of the participants are men. $21.6 \%$ of the participants are in the $18-20$ age range, $55.2 \%$ are in the $21-24$ age range, and $23.2 \%$ are over 25 years old. $89.2 \%$ are single, $10.8 \%$ are married. The monthly income of $68 \%$ is below 1000 TL. $22.4 \%$ of them have a monthly income between 1000-1999 TL. The monthly income of $9.6 \%$ is over 2000 TL.

\subsection{Confirmatory Factor Analysis}

Confirmatory factor analysis divides observed variables into a small number of latent variables by using covariance structure of data (Albright, 2008:2). After confirmatory factor analysis, it was understood that this study contained six factors including financial risk of delivery, product risk of delivery, non-delivery risk and time risk of delivery, online purchase attitude and online purchase intention. Thus, perceived delivery risk of consumers composed of financial risk, product risk, nondelivery risk and time risk. Table 2 shows factors, the items of each factor, their factor loadings, the goodness of fit statistics and the values of Cronbach's alpha, CR and AVE. 
Table 2. The Result of Confirmatory Factor Analysis

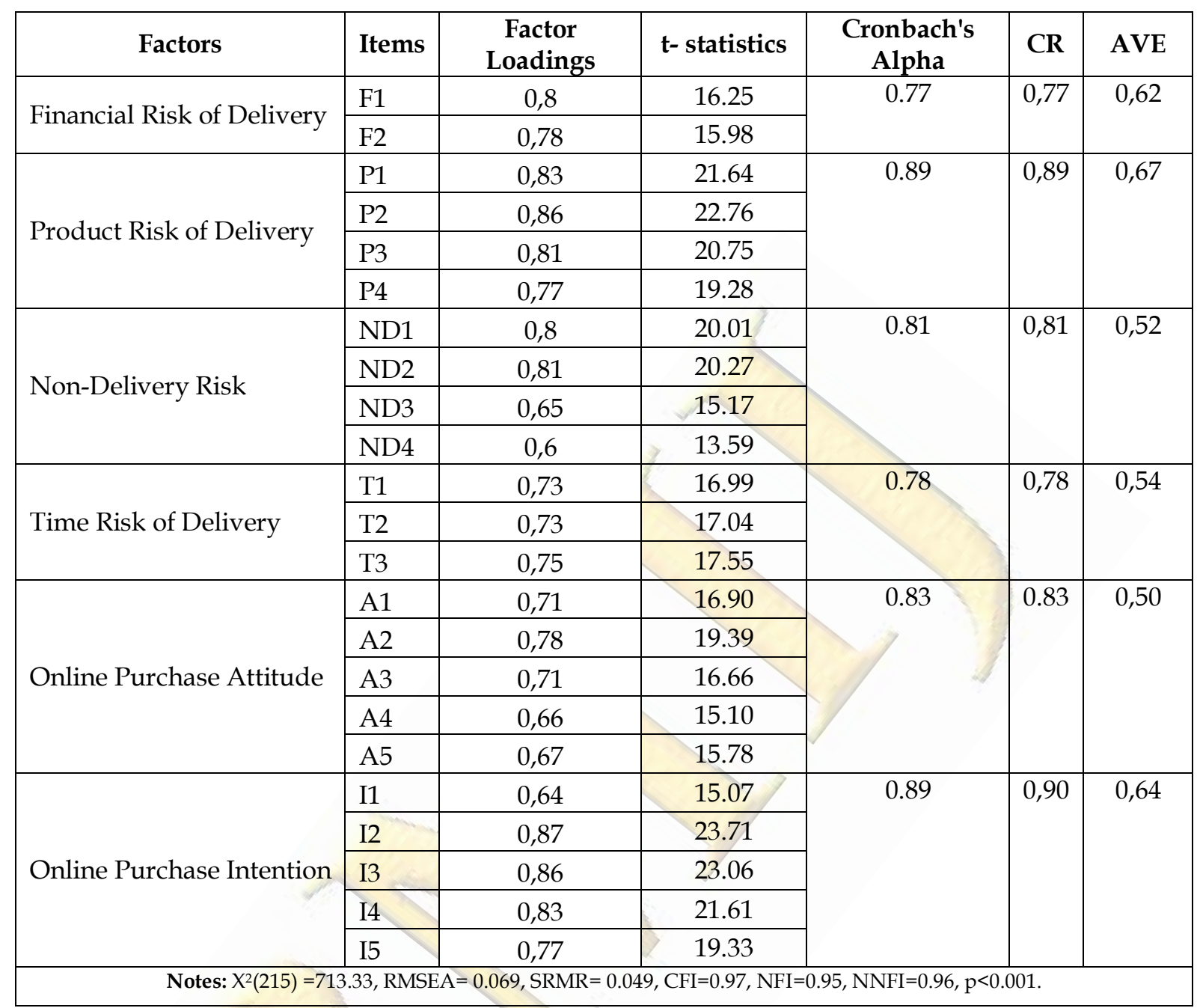

According to Table 2, $\chi 2$ test at 0.001 significance level and 215 degrees of freedom took the value of 713.33. $t$-Test results of each item are statistically significant at the 0.001 significance level. RMSEA and SRMR values show the error rates in the model so that, it is recommended to have values close to zero for a good fit model (İlhan \& Çetin, 2014:31). RMSEA value was 0.069, and SRMR took the value of 0.049 . Other indices which are used to evaluate the goodness of fit of the model are NFI, NNFI and CFI values. They take values range between 0 and 1 . Higher values for these statistics are related with a good model fit (Schermelleh- Engel et al.,2003:52). NFI was 0.95, NNFI was 0.96 and CFI was 0.97 so that these values indicate the excellent fit. Since all model fit indices indicate a good fit, confirmatory factor analysis is statistically significant. 


\subsection{Measurement of Reliability and Validity}

Different statistics were used to evaluate the reliability and validity of the study, such as Cronbach's alpha coefficient $(\alpha)$, composite reliability (CR), and convergent validity. Cronbach's Alpha is the most used method to assess internal consistency (Hong et al., 2016:17). Alpha can take a value between 0 and 1. Higher alpha value means higher reliability. Cronbach's Alpha value which is more than 0.7 reflects an excellent internal consistency (Sharma, 2016: 273). Composite Reliability is another statistical method to measure scale reliability and is generally used in confirmative factor analysis. Composite reliability value should be more than 0.7 for a right internal consistency (Cao et al.,2017:406). Since all values of Cronbach's alpha and CR in Table 2 are higher than 0.7 , it can be said that the internal consistency of this study is higher, and the scale is reliable.

On the other hand, the average variance extracted (AVE) scores were used to evaluate the convergent validity of the study. Convergent validity indicates that the expressions related to the variables are related to each other and the factor they formed. It is recommended for convergent validity that all CR values for the scale should be greater than the AVE values, and the AVE values should be greater than 0.5 (Yaşlığlu, 2017:82). Since all AVE values were more significant than 0,5, and CR values were more significant than AVE values, the survey data had a good convergent validity.

\subsection{Hypothesis Testing}

The second stage of this study is to test the hypotheses. Hypotheses which are shown in the conceptual model in Figure 1 were tested by path analysis. Path analysis is a statistical measurement which use multiple regressions to investigate the relationships between dependent and independent variables. The results of path analysis are indicated in Table 3 below. 
Table 3. The Results of Path Analysis

\begin{tabular}{|c|l|c|c|c|}
\hline Hypotheses & \multicolumn{1}{c|}{ Path } & $\begin{array}{c}\text { Standardised } \\
\text { Path Coefficients }\end{array}$ & t-statistics & Interpretation \\
\hline $\mathrm{H}_{1}$ & $\begin{array}{l}\text { Financial Risk of Delivery } \rightarrow \\
\text { Online Purchase Attitude }\end{array}$ & -0.31 & -4.70 & Supported \\
\hline $\mathrm{H}_{2}$ & $\begin{array}{l}\text { Product Risk of Delivery } \rightarrow \\
\text { Online Purchase Attitude }\end{array}$ & -0.11 & -1.12 & Unsupported \\
\hline $\mathrm{H}_{3}$ & $\begin{array}{l}\text { Non- Delivery Risk } \rightarrow \\
\text { Online Purchase Attitude }\end{array}$ & -0.24 & -2.30 & Supported \\
\hline $\mathrm{H}_{4}$ & $\begin{array}{l}\text { Time Risk of Delivery } \rightarrow \\
\text { Online Purchase Attitude }\end{array}$ & -0.37 & -4.09 & Supported \\
\hline $\mathrm{H}_{5}$ & $\begin{array}{l}\text { Online Purchase Attitude } \rightarrow \\
\text { Online Purchase Intention }\end{array}$ & 0.74 & -10.99 & Supported \\
\hline $\begin{array}{l}\text { Structural Equations: } \\
\text { Intention }=0.74^{*} \text { Attitude }\left(R^{2}=0.54\right) \\
\text { Attitude }=-0.31^{*} \text { Financial Risk -0.37*Time Risk-0.24* Non-Delivery Risk-0.11-Product Risk }\left(\mathrm{R}^{2}=0.28\right)\end{array}$ \\
\hline \multicolumn{5}{|r}{ Notes: $\mathrm{X}^{2}(219)=736.17$, RMSEA $=0.070$, SRMR $=0.056$, CFI $=0.96$, NFI $=0.95$, NNFI $=0.96, p<0.001$} \\
\hline
\end{tabular}

According to Table 3, $\chi 2$ test at 0.001 significance level and 219 degrees of freedom took the value of 736.17. RMSEA value was 0.070, and SRMR took the value of 0.056. Since closer value to the zero is an indicator of good fit (İlhan \& Çetin, 2014:31), it is understood that this model had a good fit by evaluating RMSEA and SRMR values. NFI was 0.95, NNFI and CFI took the value of 0.96 so that these values were interpreted as an indicator of good fit (Schermelleh- Engel et al.,2003:52). Since all model fit indices indicate a good fit, confirmatory factor analysis is statistically significant.

However, when standardised path coefficients examine the relationships between dependent and independent variables, it is understood that the relationships among perceived delivery risk factors and online purchase attitude were negative. Structural equation of online purchase attitude shows that time risk of delivery, the financial risk of delivery, non-delivery risk and product risk of delivery had a weighted effect on the online purchasing behaviour of consumers, respectively. These factors can be used to explain $28 \%$ of online purchase attitude. On the other hand, Table 3 indicates that there is a strong positive relationship between online purchase attitude and intention. Online purchase attitude explained $54 \%$ of online purchase intention. When t-statistics are evaluated in order to test the hypotheses, it is understood that all t-test results were statistically significant except than the 
relationship between product risk of delivery and online purchase attitude. Thus, after path analysis, $\mathrm{H}_{1}, \mathrm{H}_{3}, \mathrm{H}_{4}$ and $\mathrm{H}_{5}$ were accepted but, despite the negative relationship between product risk and online purchase attitude, $\mathrm{H}_{2}$ was rejected as this relationship was not statistically significant.

\section{CONCLUSION}

This study examined the perceived risk of online shopping in terms of the delivery process. Thus, it highlighted the necessary components of perceived delivery risk in online shopping and the relationships among these risk factors, online purchase attitude and online purchase intention. In this study, the components of perceived delivery risk were investigated by confirmatory factor analysis, and it was noticed that perceived delivery risk included the financial risk of delivery, product risk of delivery, non-delivery risk and time risk of delivery. The result of path analysis indicated that a negative relationship between all delivery risk factors and online purchase attitude existed, and this result was consistent with the studies in the literature (Ariff et al., 2014; Javadi et al., 2012). Mostly, time and financial risk of delivery had a higher impact on online purchase attitude. These findings emphasised the importance of delivery time and cost of delivery on consumers' attitude. Non-delivery risk also harmed online purchase attitude, but it was noticed that the weight of impact was not as healthy as the impacts of time and financial risk of delivery. It was assumed that although nondelivery of the product was an important concern for consumers in online shopping, the tracking system used in the delivery process lightened the effect of non-delivery risk on online purchase attitude. Although the relationship between product risk of delivery and online consumer attitude was negative, this relationship was not supported by this study due to the insignificance of $t$-statistics due to the insignificance of t-statistics. It is believed that the product return policy of organisations had a reliever effect on consumers' perception of product risk in the delivery process. The effect of online purchase on online purchase intention was also tested, and it was found that online purchase attitude was an important determinant of online purchase intention. This finding supported the studies in the literature (Javadi et al., 2012; Lopez-Nicholas \& Molina-Castello, 2008). 
This study had particular limitations. In this study convenience sampling was used due to the temporal and financial constraints. For this reason, data were collected only from students. Although the findings of this study cannot be generalised because of the sampling techniques used in data collection, this study provides a significant contribution to both literature and business organisations. The contribution of this study to the literature was to fill the gap in the literature and guide future studies.

Regarding the considerable impacts of delivery risk-on attitude, intention, behaviour and satisfaction of consumers, the necessity of investigation of perceived delivery risk of online consumers was noticed. However, a limited number of studies investigated the delivery risk in online shopping. When these studies were examined, it was understood that delivery risk was only probed in general in these studies. Thus, the findings of this study were thought to guide future studies by filling an important gap in the literature in terms of revealing the factors that constitute the delivery risk, analysing the effects of these factors on online purchasing attitude separately, and examining the relationship between online purchasing attitude and online purchasing intention.

On the other hand, the findings of this study emphasised the importance of the delivery process in online shopping. When consumers' risk perception of delivery increased, the attitude and intention of consumers to purchase the product decreased. Although non-delivery risk and product risk can be assumed to relieve with tracking system and product return policy of organisations, delivery time and cost have been still a paramount concern of consumers in online shopping. It is recommended that businesses should develop strategies to minimise the delivery cost and time so that they can increase online sales.

In this study, the effect of risk reliever on online purchase attitude was not studied. However, it was assumed that various risk relievers eased the effects of nondelivery risk and product risk of delivery on online purchase attitude. Further studies can examine the risk relievers of the delivery process and the moderator role of risk relievers in terms of delivery risk in online shopping. 


\section{REFERENCES}

Albright, J. J. (2008). Confirmatory Factor Analysis Using Amos, LISREL, and Mplus http://www.iu.edu/ statmath/stat/all/cfa/cfa2008.pdf (07.02.2020).

Ariff, M. S. M., Sylvester, M., Zakuan, N., Ismail, K., \& Ali, K. M. (2014). Consumer perceived risk, attitude and online shopping behaviour; empirical evidence from Malaysia. In IOP Conference Series: Materials Science and Engineering (Vol. 58, No. 1, p. 012007). IOP Publishing (1-10).

Başyazıcıoğlu, H. N. \& Leblebici-Koçer, L. (2018). Investigation of Consumers' Attitudes toward Mobile Private Shopping Applications with Uses and Gratification Approach. Yenihan. B., B. D. Saripek ve G. Cerev (eds). A Critical Review in Social Sciences içinde (ss. 107-119). Londra: Frontpage Publication.

Bhatnagar, A., \& Ghose, S. (2004). Segmenting consumers based on the benefits and risks of Internet shopping. Journal of Business Research, 57(12), 1352-1360.

Cao, Y., Ajjan, H., \& Hong, P. (2018). Post-purchase shipping and customer service experiences in online shopping and their impact on customer satisfaction. Asia Pacific Journal of Marketing and Logistics, 30 (2), 400-416.

Chang, C. (2011). The effect of the number of product subcategories on perceived variety and shopping experience in an online store. Journal of Interactive Marketing, 25(3), 159-168.

Choi, J., \& Lee, K. H. (2003). Risk perception and e-shopping: a cross-cultural study. Journal of Fashion Marketing and Management: An International Journal, 7(1), 49-64.

Crespo, A.H., Del Bosque, I. R. ve De los Salmones Sanchez, M. M. G. (2009). The influence of perceived risk on internet shopping behavior: a multidimensional perspective. Journal of Risk Research, 12(2), 259-277.

Deloitte. (2019). E-Ticaretin Gelişimi, Sınırların Aşılması ve Yeni Normlar. https://www.eticaretraporu.org/wp-content/uploads/2019/05/DD-TUSIAD-ETicaret-Raporu2019.pdf (07.02.2020).

Dowling, G. R., \& Staelin, R. (1994). A model of perceived risk and intended risk-handling activity. Journal of consumer research, 21(1), 119-134.

Featherman, M. S., \& Pavlou, P. A. (2003). Predicting e-services adoption: a perceived risk facets perspective. International journal of human-computer studies, 59(4), 451-474.

Forsythe, S., Liu, C., Shannon, D., \& Gardner, L. C. (2006). Development of a scale to measure the perceived benefits and risks of online shopping. Journal of interactive marketing, 20(2), 55-75.

Hassan, A. M., Kunz, M. B., Pearson, A. W., \& Mohamed, F. A. (2006). Conceptualisation and measurement of perceived risk in online shopping. Marketing Management Journal, 16(1), 138-147.

Hong, L. M., Zulkiffli, W. F. W., \& Hamsani, N. H. (2016). The impact of perceived risks towards customer attitude in online shopping. International Journal, 1(2), 13-21.

Hong, Z., \& Yi, L. (2012). Research on the influence of perceived risk in consumer on-line purchasing decision. Physics procedia, 24, 1304-1310. 
HOOTIE \& We are social. (2019). Global Digital Report 2019: World's internet users pass the 4 billion mark. https://wearesocial.com/blog/2019/01/digital-2019-global-internet-use-accelerates (07.02.2020).

Iconaru, C. (2012). Perceived risk when buying online: Evidence from a semi-structured interview. Studia Universitatis Vasile Goldiş, Arad-Seria Ştiințe Economice, 22(1+ 2), 63-73.

İlhan, M., \& Çetin, B. (2014). LISREL ve AMOS programları kullanılarak gerçekleştirilen yapısal eşitlik modeli (yem) analizlerine ilişkin sonuçların karşılaştırılması. Eğitimde ve Psikolojide Ölçme ve Değerlendirme Dergisi, 5(2), $26-42$.

Javadi, M., Dolatabadi, H., Nourbakhsh, M., Poursaeedi, A. \& Asadollahi, A. (2012). An analysis of factors affecting on online shopping behavior of consumers. International Journal of Marketing Studies, 4(5), 81-98.

Keeney, R. L. (1999). The value of internet commerce to the customer [J]. Management Science, 45(4), 85-161.

Ko, H., Jung, J., Kim J. \& Shim S. W. (2004). Cross-cultural differences in perceived risk of online shopping. Journal of Interactive Advertising, 4(2),20-29.

Lipsman, A. (2019). Global Ecommerce 2019: Ecommerce Continues Strong Gains Amid Global Economic Uncertainty. eMarketer. https://www.emarketer.com/content/global-ecommerce-2019. (07.02.2020).

Lo'pez-Nicola's, C., Molina-Castillo, F.J. ve Bouwmanb, H. (2008). An assessment of advanced mobile services acceptance: Contributions from TAM and diffusion theory models. Information \& Management, 45, 359-364.

Mitchell, V. W. (1999). Consumer perceived risk: conceptualisations and models. European Journal of marketing.33(1/2), 163-195.

Naiyi, Y. E. (2004). Dimensions of consumer's perceived risk in online shopping. Journal of Electronic Science and Technology, 2(3), 177-182.

Nepomuceno, M. N., Laroche, M. Ve Richard, M.O. (2014). How to reduce perceived risk when buying online: The interactions between intangibility, product knowledge, brand familiarity, privacy and security concerns. Journal of Retailing and Consumer Services, 21, 619-629.

Nyshadham, E. A. (2000). Privacy policies of air travel web sites: a survey and analysis. Journal of Air Transport Management, 6(3), 143-152.

Ozen, H., \& Engizek, N. (2014). Shopping online without thinking: being emotional or rational? Asia pacific journal of marketing and logistics.26(1), 78-93.

Pappas, N. (2016). Marketing strategies, perceived risks, and consumer trust in online buying behaviour. Journal of Retailing and Consumer Services, 29, 92-103.

Schermelleh-Engel, K., Moosbrugger, H., \& Müller, H. (2003). Evaluating the fit of structural equation models: Tests of significance and descriptive goodness-of-fit measures. Methods of psychological research online, 8(2), 23-74. 
Sharma, B. (2016). A focus on reliability in developmental research through Cronbach's Alpha among medical, dental, and paramedical professionals. Asian Pacific Journal of Health Sciences, 3(4), 271-278.

Suhaily, L., \& Soelasih, Y. (2017). What effects repurchase intention of online shopping. International Business Research, 10(12), 113-122.

Thakur, R., \& Srivastava, M. (2015). A study on the impact of consumer risk perception and innovativeness on online shopping in India. International Journal of Retail \& Distribution Management.43(2), 148-166.

TUBISAD. (2019). Türkiye'de E-Ticaret 2018 Pazar Büyüklüğü. http://www.tubisad.org.tr/tr/images/pdf/tubisad_2019_e-ticaret_sunum_tr.pdf. (07.02.2020).

Wai, K., Dastane, O., Johari, Z., \& Ismail, N. B. (2019). Perceived risk factors affecting consumers' online shopping behaviour. The Journal of Asian Finance, Economics and Business, 6(4), 246-260.

Yaşlığlu, M. M. (2017). Sosyal bilimlerde faktör analizi ve geçerlilik: Keşfedici ve doğrulayıcı faktör analizlerinin kullanılması. İstanbul Üniversitesi İşletme Fakültesi Dergisi, 46, 74-85.

Zhang L., Tan W., Xu Y., Tan G. (2011) Dimensions of Perceived Risk and Their Influence on Consumers' Purchasing Behavior in the Overall Process of B2C (1-10). In: Zhang L., Zhang C. (eds) Engineering Education and Management. Lecture Notes in Electrical Engineering, vol 111. Springer, Berlin, Heidelberg. https://doi.org/10.1007/978-3-642-24823-8_1

Zheng, L., Favier, M., Huang, P., ve Coat, F. (2012). Chinese consumer perceived risk and risk relievers in e-shopping for clothing. Journal of Electronic Commerce Research, 13(3), 255-274. 